\title{
INFLUENCE OF SMOKING HABIT ON AGE AT DIAGNOSIS OF BREAST CANCER
}

Mehrdad Rajaei ${ }^{1}$, Shapour Omidvari ${ }^{2}$, Mostafa Saadat ${ }^{1}$

${ }^{1}$ Department of Biology, College of Sciences, Shiraz University, Shiraz 71454, Iran

${ }^{2}$ Department of Chemotherapy, Shiraz University of Medical Sciences, Shiraz, Iran

\author{
UTICAJ PUŠAČKE NAVIKE NA STAROSNU DOB PACIJENATA \\ U TRENUTKU POSTAVLJANJA DIJAGNOZE KARCINOMA DOJKE \\ Mehrdad Rajaei ${ }^{1}$, Shapour Omidvari ${ }^{2}$, Mostafa Saadat ${ }^{1}$ \\ ${ }^{1}$ Odsek za biologiju, Fakultet prirodnih nauka, Univerzitet Širaz, Širaz 71454, Iran \\ ${ }^{2}$ Odsek za hemoterapiju, Univerzitet medicinskih nauka Širaz, Širaz, Iran
}

\begin{abstract}
No studies have yet investigated the influence of smoking on age at diagnosis of breast cancer. Therefore, the present study was carried out. This study consisted of 605 females with pathologically confirmed primary adenocarcinoma of the breast and 438 healthy females matched by age. Among our participants, 86 (14.2\%) patients and 62 (14.1\%) control subjects, respectively, were smokers. Based on a Cox regression model, evidence suggested that smoking status influenced the age at diagnosis of breast cancer ( $H R=0.78,95 \%$ CI: 0.62-0.99, $P=0.040)$. After stratification of the patients according to their menopausal status, the same results were obtained. The present study indicated that non-smokers have a lower age at diagnosis in comparison with patients who smoke.
\end{abstract}

Keywords: Age at diagnosis, breast cancer, smoking Habit

\section{SAŽETAK}

Do sada nisu sprovodena istraživanja kojima se ispituje uticaj pušačke navike na starosnu dob u trenutku postavljanja dijagnoze karcinoma dojke. Iz tog razloga je sprovedena ova studija. Studija je sprovedena na 605 ispitanica sa patohistološki potvrdenim primarnim adenokarcinomom dojke, i 438 zdravih ispitanica odgovarajuće starosne dobi. 86 (14.2\%) ispitanica u grupi sa potvrdenom dijagnozom, odnosno, 62 (14.1\%) iz kontrolne grupe su bile pušači. Prema Cox modelu regresije dokazana je povezanost pušačkog statusa i starosne dobi u trenutku postavljanja dijagnoze karcinoma dojke (HR=0.78, 95\% CI: 0.62-0.99, $P=0.040)$. Treba napomenuti i da su isti rezultati dobijeni nakon stratifkacije ispitanica prema menopauzalnom statusu. Ova studija je pokazala da su nepušači u trenutku postavljanja dijagnoze karcinoma dojke u mladoj životnoj dobi u odnosu na pušače.

Ključne reči: starosna dob u trenutku postavljanja dijagnoze, karcinom dojke, pušenje

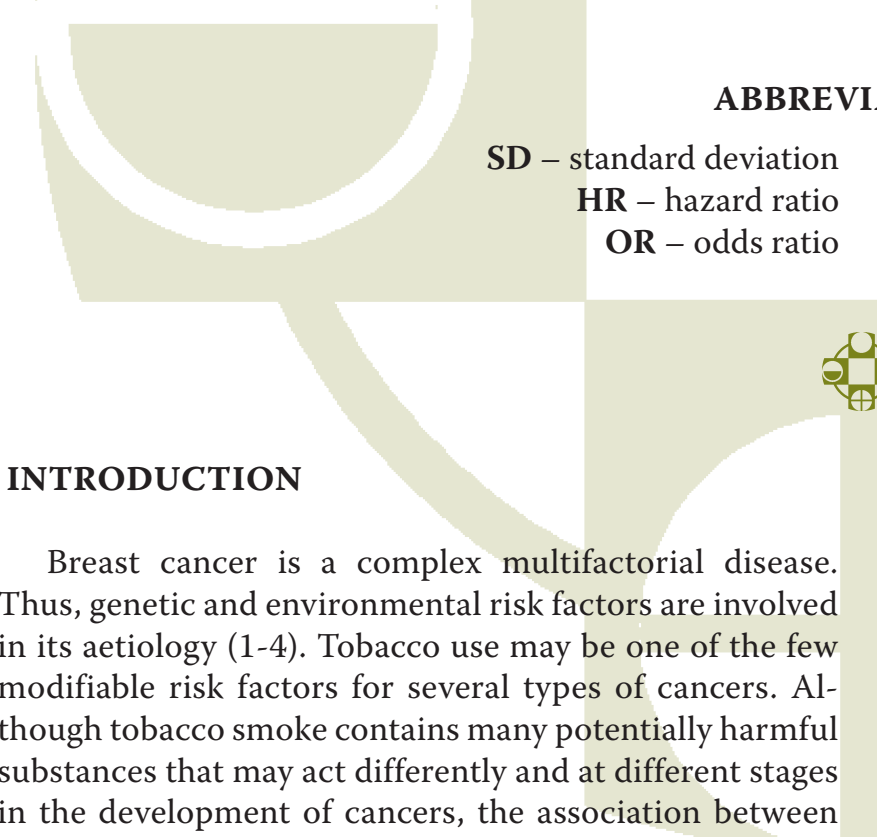

smoking and breast cancer risk remains unclear (5-11). Moderate or strong associations between smoking and breast cancer risk have been observed in some studies (611). Several prospective studies have focused specifically on the association between smoking and breast cancer survival rate, however, the results of these studies are not consistent (12-15). 
While a smoking habit is one of the most preventable causes of cancers, based on our knowledge, there is no study that investigates the influence of smoking on age at diagnosis of breast cancer. Therefore, the present study was carried out to study this relationship.

\section{MATERIALS AND METHODS}

A total number of 605 patients with pathologically confirmed primary breast adenocarcinoma were recruited from the chemotherapy department of the Nemazi hospital in Shiraz (Fars province, southwest Iran) from September 2008 to June 2011. The mean age at diagnosis of breast cancer (SD; Min-Max; Median) was 45.7 (10.7; 22-83; 45). Age frequency-matched control subjects (438 people) were randomly selected from healthy female blood donors. The mean age of the control group (SD; Min-Max; Median) was 46.7 (10.6; 22-80; 45).

The Iranian population is one of the most heterogeneous populations in the world $(16,17)$. Therefore, we selected our patients and control subjects from Persian/ Muslims (Caucasian) living in the Fars province (southwest Iran).

Family medical history, specifically the incidence of breast cancer (positive, negative), and the smoking status (smoker, non-smoker) of the patients and control subjects were collected via personal interviews. A woman with at least one first-degree relative with breast cancer was considered to have a positive family history. Informed consent was obtained from each subject before being enrolled in the study, and the study was approved by the institutional review board at our department.

The association between smoking status, family history and the risk of breast cancer was assessed by calculating odds ratios (ORs) and 95\% confidence intervals (CIs). To determine the effects of smoking status and family history on age at diagnosis of breast cancer, the Kaplan-Meier survival analysis and the Cox proportional hazards regression model were used. In the analysis, breast cancer was defined as the event, and the age at diagnosis was included in the analysis as time to event. Statistical analysis was performed using the Statistical Package for Social Sciences (SPSS Inc., Chicago, IL, USA) (version 11.5). A probability of $\mathrm{P}<0.05$ was considered statistically significant.

\section{RESULTS}

Among our participants, 86 (14.2\%) patients and 62 (14.1\%) control subjects, respectively, were smokers. There was no association between smoking status and risk of breast cancer $(\mathrm{OR}=1.01,95 \% \mathrm{CI}$ : 0.71-1.43, $\mathrm{P}=0.978)$. Like many studies (18), family history significantly differed between patient cases and control subjects $(4.6 \%$ in cases vs $2.1 \%$ in control subjects; $\mathrm{OR}=2.31,95 \% \mathrm{CI}: 1.08-4.95$, $\mathrm{P}=0.031)$.

Table 1 shows the distribution of age among newly diagnosed breast cancer patients and control subjects according to their smoking habit. The Kaplan-Meier survival analysis revealed that a smoking habit was associated with age at diagnosis of breast cancer (log rank statistic $=4.440$, $\mathrm{df}=1, \mathrm{P}=0.035$ ). A family history of breast cancer was also associated with age at diagnosis of breast cancer (log rank statistic $=1.609, \mathrm{df}=1, \mathrm{P}=0.205)$. In the Cox proportional hazards regression model, smoking status and family history were treated as categorical variables. Hazard ratios (HR) and 95\% of confidence intervals (CIs) for the categorical variables were estimated. Based on the Cox regression model, there was an association between smoking status and age at diagnosis of breast cancer $(\mathrm{HR}=0.78,95 \% \mathrm{CI}$ : 0.62-0.99, $\mathrm{P}=0.040)$. This means that non-smokers have a lower age at diagnosis in comparison to patients who smoke. After stratification of the patients according to their menopausal status, the same results were obtained.

\section{DISCUSSION}

In the present case-control study, we investigated two associations: 1) the association between smoking habit and breast cancer risk, and 2) the association between smoking habit and age at diagnosis of breast cancer. Although breast cancer has not been previously regarded as a smoking related cancer (5), recent studies haves revealed a positive association between tobacco smoke and breast cancer risk (6-11). Based on the present study, there was no significant association between a smoking habit and a risk of breast cancer. This finding is consistence with some reports (see ref. 5) and is not consistence with other reports (6-11).

We found that the association between smoking status and age at diagnosis of breast cancer was significant.

Table 1. Distribution of age among breast cancer patients and control subjects stratified by their smoking status

\begin{tabular}{|c|c|c|c|c|c|c|c|c|}
\hline \multirow[t]{3}{*}{ Smoking status } & \multicolumn{4}{|c|}{ Breast cancer patients } & \multicolumn{4}{|c|}{ Control subjects } \\
\hline & \multicolumn{4}{|c|}{ Age at diagnosis (Years) } & \multicolumn{4}{|c|}{ Current age (Years) } \\
\hline & $\mathbf{n}$ & Mean & SD & Median & $\mathbf{n}$ & Mean & SD & Median \\
\hline Non-Smokers & 519 & 45.4 & 10.6 & 44.0 & 376 & 46.1 & 10.5 & 44.5 \\
\hline Smokers & 86 & 47.7 & 11.4 & 47.0 & 62 & 50.5 & 10.1 & 50.0 \\
\hline Total & 605 & 45.7 & 10.7 & 45.0 & 438 & 46.7 & 10.6 & 45.0 \\
\hline
\end{tabular}


Epidemiological studies have indicated that women who smoke might experience decreased risk of breast cancer as a result of antiestrogenic effects (19). Therefore, it could be concluded that the antiestrogenic effects of tobacco smoke, at least in part, are a mechanism for explaining our present findings.

It should be mentioned that in Iran, breast cancer patients are younger than breast cancer patients in Western countries (3). We know that susceptibility to breast cancer is a multifactorial trait and its risk factors (either genetic components or environmental factors) may differ between populations. Tobacco smoke contains several thousand various compounds that are carcinogenic to humans, and metabolites of tobacco smoke have been found in the breast fluid and tissue of smokers (20,21). Many of the carcinogenic compounds present in tobacco smoke are substrates of phase I enzymes, represented by the family of cytochrome P450 enzymes $(22,23)$. Certain genotypes of several genetic polymorphisms in enzymes involved in the metabolism of xenobiotics (such as P450s and antioxidant enzymes) have been suggested to alter the risk of breast cancer (24-27). The inconsistency of the findings between studies might be at attributed to differences between population gene pools, environmental factors and the interaction between the two. The main limitations of the present study are the small sample size, the lack of data on duration of smoking and/or passive smoking and possible confounding by other factors, such as diet, including phytoestrogen intake, cannot be excluded. In the future, our present finding should be confirmed by large-scale studies.

\section{Conflict of Interest}

The authors have no financial or non-financial competing interests.

\section{Acknowledgements}

The authors are indebted to the participants of this study for their cooperation. The authors are indebted to Dr. Maryam Ansari-Lari for her critical reading of the manuscript and her contribution in discussion. This study was supported by Shiraz University.

\section{REFERENCES}

1. Enger SM, Ross RK, Henderson B, Bernstein L. Breastfeeding history, pregnancy experience and risk of breast cancer. Br J Cancer 1997;76:118-123.

2. Rosa-Rosa JM, Pita G, Urioste M, Llort G, Brunet J, Lázaro C, Blanco I, Ramón Y, Cajal T, Díez O, de la Hoya M, Caldés T, Tejada MI, González-Neira A, Benítez J. Genome-wide linkage scan reveals three putative breast-cancer susceptibility loci. Am J Hum Genet 2009; 84:115-122.

3. Saadat M, Ansari-Lari M. Polymorphism of XRCC1 (at codon 399) and susceptibility to breast cancer, a meta-analysis of the literatures. Breast Cancer Res Treat 2009;115:137-144.

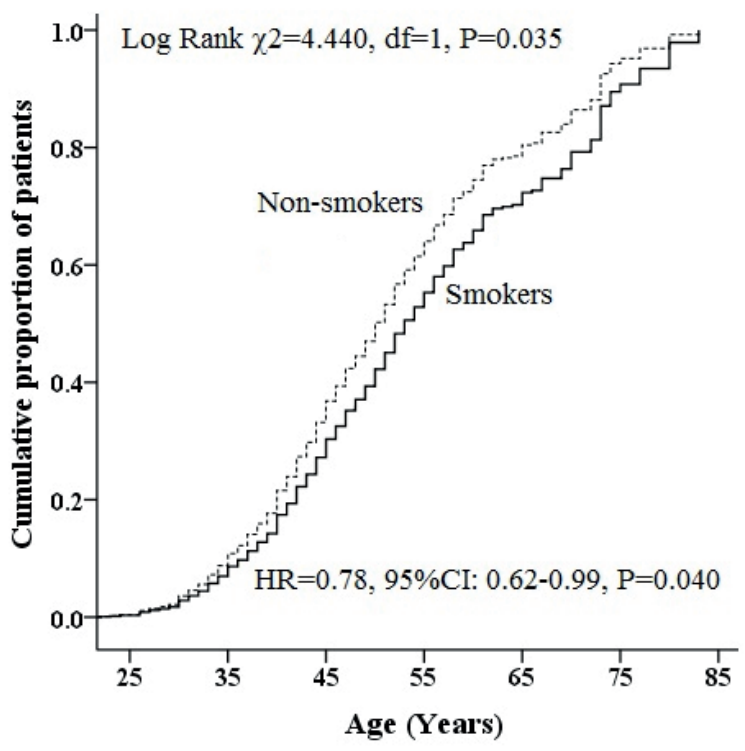

Figure 1. Comparison of age at diagnosis of breast cancer between smokers and non-smokers, after adjustment for family history

4. Saadat M. Offspring sex ratio at birth and maternal breast cancer risk: A case-control study and meta-analysis of literature. EXCLI Journal 2010;9:76-81.

5. Collaborative group on Hormonal Factors in Breast cancer. Alcohol, tobacco and breast cancer - collaborative reanalysis of individual data from 53 epidemiological studies, including 58515 women with breast cancer and 95067 women without the disease. Br J Cancer 2002; 87:1234-1245.

6. Ueji M, Ueno E. Osei-Hirayama D, Saito T, Takahashi H, Kano K. Risk factors for breast cancer among Japanese women: a case-control study in Ibaraki, Japan. Breast Cancer 1998;5: 351-358.

7. Nagata C, Mizoue T, Tanaka K, Tsuji I, Wakai K, Inoue M, Tsugane S. Research Group for the Development and Evaluation of Cancer Prevention Strategies in Japan. Tobacco smoking and breast cancer risk: an evaluation based on a systematic review of epidemiological evidence among the Japanese population. Jap J Clil Oncol 2006;36:387-394.

8. Zhang X, Condon JR, Rumbold AR, Cunningham J, Roder DM. Estimating cancer incidence in Indigenous Australians. Aust N Z J Public Health 2011;35:477-485.

9. Rollison DE, Brownson RC, Hathcock HL, Newschaffer CJ. Case-control study of tobacco smoke exposure and breast cancer risk in Delaware. BMC Cancer 2008;8:157.

10. Cotterchio M, Mirea L, Ozcelik H, Kreiger N. Active cigarette smoking, variants in carcinogen metabolism genes and breast cancer risk among pre- and postmenopausal women in Ontario, Canada. Breast J 2014;20:468-480. 
11. Podkowa N, Komasińska P, Roszak M, Gryczka R, Grodecka-Gazdecka S, Łacka K. Health behaviours among women diagnosed with breast tumours. Pol Merkur Lekarski 2014;37:153-158.

12. Ewertz M, Gillanders S, Meyer L, Zedeler K. Survival of breast cancer patients in relation to factors which affect the risk of developing breast cancer. Int J Cancer 1991; 49:526-530.

13. Calle EE, Miracle-McMahill HL, Thun MJ, Heath CW Jr. Cigarette smoking and risk of fatal breast cancer. Am J Epidemiol 1994;139:1001-1007.

14. Manjer J, Andersson I, Berglund G, Bondesson L, Garne JP, Janzon L, Malina J, Matson S. Survival of women with breast cancer in relation to smoking. Eur J Surgery 2000;166:852-858.

15. Holmes MD, Murin S, Chen WY, Kroenke CH, Spiegelman D, Colditz GA. Smoking and survival after breast cancer diagnosis. Int J Cancer 2007;120:2672-2677.

16. Mohamadynejad P, Saadat M. Genetic polymorphisms of XRCC1 (at codons 194 and 399) in Shiraz population (Fars province, southern Iran). Mol Biol Rep 2008;35:669-672.

17. Rafiee L, Saadat I, Saadat M. Glutathione S-transferase genetic polymorphisms (GSTM1, GSTT1 and GSTO2) in three Iranian populations. Mol Biol Rep 2010;37:155-158.

18. Teare MD, Wallance SA, Harris M, Howell A, Birch JM. Cancer experience in the relatives of an unselected series of breast cancer patients. Br J Cancer 1994;70:102-111.

19. Osanai M, Lee GH. Nicotine-mediated suppression of the retinoic acid metabolizing enzyme CYP26A1 limits the oncogenic potential of breast cancer. Cancer Sci 2011;102:1158-1163.
20. Petrakis NL, Grurnke LD, Beelen TC, Castagnori N Jr, Craig JC. Nicotine in breast fluid of nonlactating women. Science 1978;199:303-305.

21. Li D, Wang M, Firozi PF, Chang P, Zhang W, BaerDubowska W, Moorthy B, Vulimiri SV, Goth-Goldstein R, Weyand EH, DiGiovanni J. Characterization of a major aromatic DNA adduct detected in human breast tissue. Environ Mol Mutagen 2002;39: 193-200.

22. Nakajima M, Kwon JT, Tanaka N. Relationship between interindividual differences in nicotine metabolism and CYP2A6 genetic polymorphism in humans. Clin Pharmacol Ther 2001;69:72-78.

23. Tyndale RF, Sellers EM. Genetic variation in CYP2A6mediated nicotine metabolism alters smoking behavior. Ther Drug Monit 2002;24:163-171.

24. Sergentanis TN, Economopoulos KP. GSTT1 and GSTP1 polymorphisms and breast cancer risk: a metaanalysis. Breast Cancer Res Treat 2010;121:195-202.

25. Qiu LX, Yuan H, Yu KD, Mao C, Chen B, Zhan P, Xue K, Zhang J, Hu XC. Glutathione S-transferase M1 polymorphism and breast cancer susceptibility: a metaanalysis involving 46,281 subjects. Breast Cancer Res Treat 2010;121:703-708.

26. Justenhoven C, Pentimalli D, Rabstein S, Harth V, Lotz A, Pesch B, Brüning T, Dörk T, Schürmann P, Bogdanova N, Park-Simon TW, Couch FJ, Olson JE, Fasching PA, Beckmann MW, Häberle L, Ekici A, Hall P, Czene K, Liu J, Li J, Baisch C, Hamann U, Ko YD, Brauch H. CYP2B6*6 is associated with increased breast cancer risk. Int J Cancer 2014;134:426-630.

27. Tian Z, Li YL, Zhao L, Zhang CL. Role of CYP1A2 1F polymorphism in cancer risk: evidence from a meta-analysis of 46 case-control studies. Gene 2013;524:168-174. 